\title{
CHEMINIO ŠVEITIMO PROCEDŪRŲ SU GLIKOLIO RŪGŠTIMI POVEIKIS SKIRTINGO AMŽIAUS MOTERŲ STRIJŲ PAVEIKTAI ODAI
}

\author{
Margarita Drozdova-Statkevičienė, Raimonda Rauluševičienė, Giedrė Majauskienė \\ Šv. Ignaco Lojolos kolegija, Sveikatos moksly ir technologiju katedra
}

Raktažodžiai: strijos, atrofiniai randai, odos pažeidimai, glikolio rūgštis, alfa hidroksi rūgštys.

\section{Santrauka}

Retas gali pasigirti tolygiu viso kūno odos reljefu. Vienas iš dažniausių kūno odos defektų yra strijos. Šie atrofiniai randai yra mažiau elastingi ir stangrūs, nei ịprastinè sveika oda. Gali atrodyti, kad odos strijos nedaro ittakos sveikatai, tačiau tyrimai rodo, kad 70 proc. moterų, 40 proc. paauglių ir vyrų bei 90 proc. néščiųų kenčia nuo strijų sukeliamų estetinių odos pažeidimų [20]. Dèl strijų kylančios problemos kelia emocinį stresą, nemažą kosmetinị ir estetinį rūpestí, moterys ima gèdytis savo kūno, praranda seksualumą. Vienas iš inovatyvių būdų, siūlomas rinkoje ir dažniausiai analizuojamas mokslinèje literatūroje, yra alfa hidroksi rūgščių poveikis striju paveiktai odai.

Tyrimo tikslas - nustatyti cheminio šveitimo procedūru su glikolio rūgštimi poveikị skirtingo amžiaus moterų strijų paveiktai odai.

Metodai. Kriterinès atrankos būdu buvo atrinktos dvi moterys. Amžius - 16 ir 34 metų. Tyrimo dalyvès turejjo atitikti šiuos kriterinius reikalavimus: apatinejje kūno dalyje (šlaunyse, sédmenyse) strijos: mèlynos, baltos; galèjo skųstis celiulitu. Siekiant ịvertinti taikytų priemonių poveikį strijų paveiktai odai, naudotas KLAPP odos diagnostikos aparatas nustatyti odos drégmès lygi prieš ir po procedūru. Tyrimo metu buvo daromos nuotraukos prieš ir po kiekvienos procedūros.

Tiriamosioms atlikta po 10 vienodų procedūrų su 70 proc. glikolio rūgštimi. Glikolio rūgšties ekspozicijos laikas su nuolatiniu stebejjimu siekė 10 minučių. Po glikolio rūgšties neutralizavimo proceso dèl efektyvesnių rezultatų buvo atliekamas šildomojo kremo įvyniojimas plèvele ir panaudota CARE 7 aparato šalčio funkcija (-10) ${ }^{0} \mathrm{C}$, kurios laikas buvo 10 minučių. Procedūra baigiama drèkinamuoju losjonu.
Rezultatai. Lyginant tiriamujjų rezultatus pagal amžių, abiejų rezultatai buvo teigiami. Manoma, kad 16 metų tiriamosios odos pokyčiams turèjo įtakos jaunas amžius, nes greičiau vyksta metabolizmas ir odos atsinaujinimas. Strijos labiau pasikeitė 34 metų tiriamosios sẻdmenų odos srityje, todèl galima teigti, kad amžius strijų problemos sprendimui įtakos neturejo.

Išvados. Glikolio rūgštis pagerino odos strijų būklę, tačiau procedūras su glikolio rūgštimi reikètų kartoti bei derinti su kitomis priemonėmis ar būdais. Dešimties procedūrų kursas su glikolio rūgštimi nežymiai pakeitè odos drègmès parametrus.

\section{Ivadas}

Strijos yra atrofiški odos randai, sukeliantys kosmetiniu rūpesčiu [8]. Jų atsiradimo mechanizmas siejamas su fiziniu tempimu, hormonų pokyčiais bei struktūriniais kolageno ir elastino pakitimais [14]. Sveikoje odoje randamos kolageno skaidulos tvarkingai susivijusios ị ryšulèlius, palaikančius odos vientisumą [19]. Esant strijų pažeistai odai, kolageno ryšulèliai atsidalina ir kolageno fibrilès nesuformuoja ryšulèlių [9], todèl stebimi fibroblastų kokybès pokyčiai, atsirandantys dèl fibronektino sumažejimo [4].

Literatūroje aprašyta nemažai strijų atsiradimo priežasčių. Dažniausiai ịvardijamos audinius pažeidžiančios infekcijos, mechaninis tempimo poveikis, sukeliantis jungiamojo audinio karkaso plyšimą (pvz., nèštumas, nutukimas, svorio didèjimas), paauglystèje - brendimo spurtas, dèl kurio padidèja tam tikros kūno sritys, steroidinių hormonų kiekio padidejimas, genetiniai veiksniai ir kitos ligos [5]. Strijos du su puse karto dažniau paveikia moterų kūno odą, ypač néštumo metu (90 proc.). Vyriškosios lyties atstovams dažniausios lokalizacijos vietos yra išorinès šlaunų ir juosmenskryžkaulio sritys, o moterims - šlaunys, rankų viršutinès dalys, sèdmenys bei krūtys [5].

Naujai susiformavusių strijų vietos odoje būna rausvai raudono atspalvio, gali būti niežtinčios ir šiek tiek iškilios. 
Su laiku strijų ilgis didejja ir ịgauna tamsesnę violetinę spalvą. Laikui bėgant, strijos tampa baltos ir plokščios [7].

Strijos odos paviršiuje yra opi problema daugeliui pasaulio gyventojų, todèl ieškoma įvairiu jos sprendimo priemonių. Strijų naikinimui naudojamos įvairios kosmetinès priemonès ir procedūros, glikolio rūgštis, trichloracto rūgštis, retinolio turintys produktai, hidrantų kremai, masažinius aliejus, vaistažolès, lazeris ir šviesos prietaisai, intensyvi impulsinè šviesa, frakcine fototermolizè, mikrodermabrazija ir kitos [5,8]. Mažiausiai ištirtas yra glikolio rūgšties turinčių produktų efektyvumas strijų paveiktai odai.

Glikolio rūgštis šiuo metu naudojama kosmetologijoje ir dermatologijoje. Visos alfa hidroksi rūgštys yra panašios cheminès sudèties ir pasižymi vienoda centrine dalimi, o skirtumas randamas tarp šoninių anglies grandžių ilgių. Alfa hidroksi rūgščiu veikimą ir pritaikymą lemia laikas, koncentracija ir pH [10]. Dẻl savo mažos molekulinès masès lengvai prasiskverbia pro raginį sluoksnį ir nukeliauja iki dermos.

Glikolio rūgšties paveiktas raginis sluoksnis nusisluoksniuoja, bazalinis sluoksnis gauna signalą spartesnei proliferacijai ir ląstelių siuntimui ị paviršių. Šio proceso metu pasiekiamas efektyvus epidermio atsinaujinimas [2]. Glikolio rūgštis tiesiogiai veikia fibroblastų ir keratinocitų odos matricos apykaitą, o tai efektyviai pagreitina fibroblastų kolageno sintezę [13].
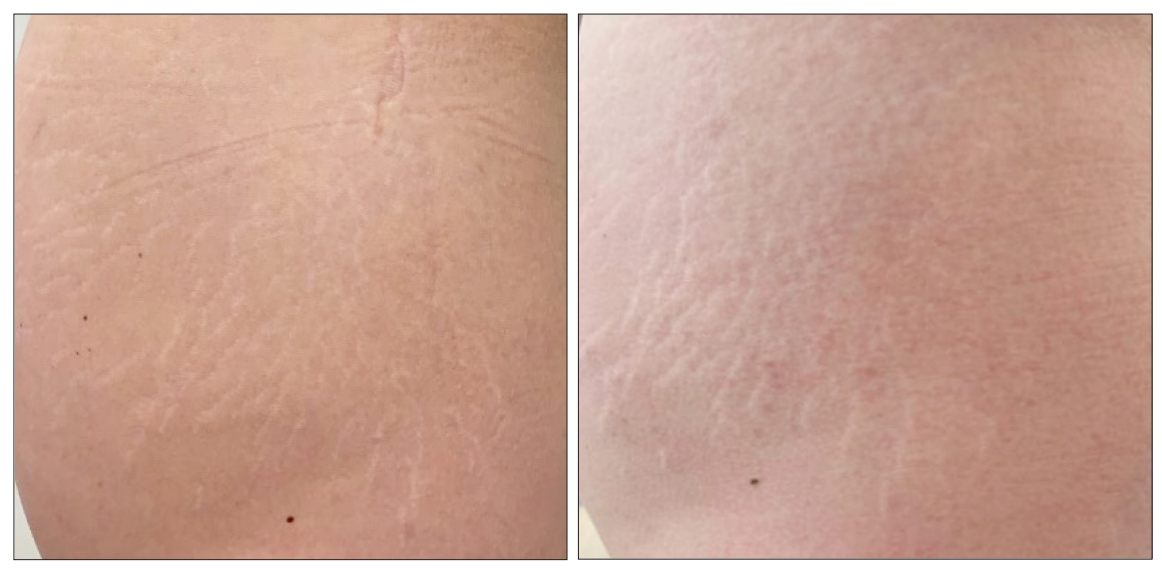

Dešiniosios pusès klubų sritis prieš procedūras Dešiniosios pusès klubų sritis po 10 procedūrų

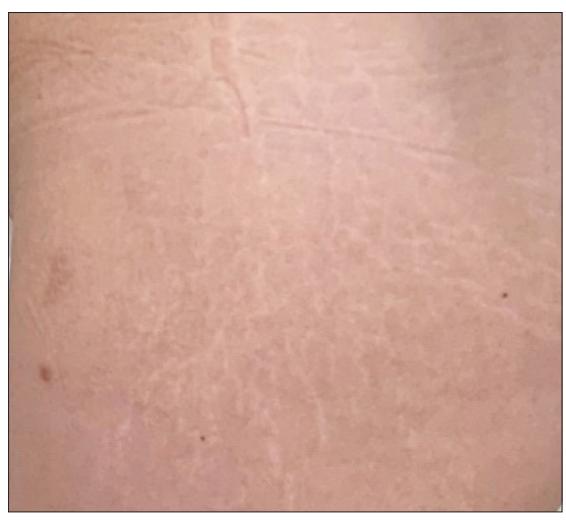

Kairiosios pusės klubų sritis prieš procedūras

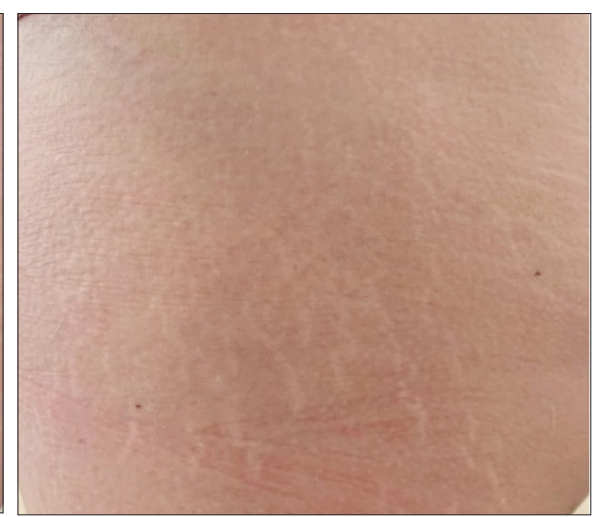

Kairiosios pusès klubų sritis po 10 procedūrų

1 pav. 34 metų tiriamosios strijų vaizdas klubų srityje prieš ir po procedūrų

Alfa hidroksi rūgštys, gebančios veikti įvairiuose odos sluoksniuose, pritaikomos ne tik spręsti įvairias veido odos problemas. Tai yra vienas iš būdų spręsti strijų paveiktos odos problemas [11].

Tyrimo tikslas - nustatyti cheminio šveitimo procedūrų su glikolio rūgštimi poveiki skirtingo amžiaus moterų strijų paveiktai odai.

\section{Tyrimo medžiaga ir metodai}

Tyrimas buvo atliktas Kauno Šv. Ignaco Lojolos kolegijoje, Sveikatos mokslų ir technologijų katedroje nuo $2020 \mathrm{~m}$. lapkričio iki $2021 \mathrm{~m}$. vasario mènesio. Tiriamieji pasirašè asmens informavimo ir sutikimo dalyvauti tyrime formą, prieš tai paaiškinus visus tyrimo ypatumus ir su tuo susijusius galimus nepatogumus. Tyrimo metu laikytasi Helsinkio deklaracijos ir Neapsaugotų tiriamųjų grupių saugumo etikos principų, kadangi tyrime dalyvavo nepilnametè.

Tiriamieji. Kriterinès atrankos būdu buvo atrinktos dvi moterys. Amžius - 16 ir 34 metų. Tyrimo dalyvès turèjo atitikti šiuos kriterinius reikalavimus: apatinèje kūno dalyje (šlaunyse, sédmenyse) odos strijos, kurios galèjo būti mèlynos, baltos; galèjo skųstis celiulitu. Abi tiriamosios sutiko atvykti i procedūras ir būti prižiūrimos namuose. 34 metų moteris pirmąsias odos strijas pastebejjo paauglystėje. Turejjusi du něštumus, kurių metu buvo ryškių svorio pakitimų. Šiuo metu tiriamosios kūno masès indeksas yra normalus. Stebimi strijų pažeidimai, kurie apima nemažus odos plotus. Strijos lokalizuojasi sèdmenų, šlaunų dalyse, matomi antros stadijos celiulitui būdingų požymių. 16 metų tiriamosios KMI didesnis. Gyvenimo būdas nejudrus. Strijos atsirado ankstyvosios paauglystès laikotarpiu. Strijų lokalizacija - 
sėdmenys, liemuo. Strijos mišrios spalvos: tiek tamsios, tiek baltos.

Tyrimo priemonès

Subjektyvioji isivertinimo skale. Tiriamujų buvo prašoma ịsivertinti savo savijautą prieš, per ir po procedūros pagal tris vertinimų grupes po 5 vertinimo kriterijus, kiekvienoje nuo 1 iki 5 balų, kur 1 - labai blogai, 5 - labai gerai.

Kliento kortele leido išsiaiškinti tiriamosios galimas kontraindikacijas: sisteminę alerginę reakciją, vietines alergijas, vartojamus vaistus, esamą ir buvusi gydymą. Atliekant rūgštines procedūras, ypač svarbus odos reaktyvumas.

Drégmès matavimas diagnostiniu aparatu. Siekiant ịvertinti taikytų priemonių poveikị strijų paveiktai odai, buvo matuojamas odos drégmès parametras KLAPP firmos odos diagnostikos aparatu. Odos drègmès rodmuo išreiškiamas procentine išraiška: 25-49 proc. labai sausa, $50-60$ proc. sausa, $61-90$ proc. normalus drègmès lygis.

Fotovizualizavimas ir vizualine apžiūra prieš kiekvieną procedūrą ir po jos. Siekiant ịvertinti išoreje pastebimus odos pokyčius, buvo atliekamos foto nuotraukos klubų, šlaunų, juosmens srityse.

Procedūroms atlikti buvo pasirinkta profesionali ODA Profesional kosmetika. Kadangi kūno problemos siekia odos gilesnius sluoksnius, dermą ir hipodermą, buvo nuspręsta naudoti glikolio rūgštį. Dèl efektyvesnių rezultatų buvo atliekamas šildomojo kremo įvyniojimas plèvele ir CARE 7 aparato šalčio funkcija $(-10)^{0} \mathrm{C}$ bei kremai, skirti naudojimui namų sąlygomis.

Tiriamosioms buvo atlikta po 10 vienodų procedūrų su 70 proc. glikolio rūgštimi, prieš tai nuvalant pasirinktas problemines sritis 10 proc. glikolio prausikliu. Ekspozicijos laikas nesiskyrè visų procedūrų metu.
Buvo laikoma 10 minučių, vèliau neutralizuojama. Procedūros pabaigoje šildančio kremo įtrepimui buvo naudojama CARE 7 aparato šalčio funkcija $(-10){ }^{\circ} \mathrm{C}$.

\section{Tyrimo rezultatai}

Pagrindinis vertinamas rezultatas - abiejų tiriamujų strijų pokyčiai. Atlikus vertinimą prieš procedūrų kursą, nustatyta, kad abi tiriamosios turi strijų pažeistą odą. Dalis strijų buvo tamsios spalvos, kuri rodo, kad jos bus labiau paveikios procedūroms, nes dar turi kraujotaką. 34 metų tiriamosios odos pažeidimų vietos: sèdmenys ir klubai. 16 metų tiriamosios odos pažeidimų vietos: sèdmenys ir liemuo.

34 metų tiriamajai pradedant procedūrų kursą, pažeistose kūno vietose stebimos baltos spalvos strijos, labiausiai lokalizuotos klubų srityse. Mèlynos spalvos strijos lokalizuojasi ties dešinès pusès sèdmens dalimi. Strijos ganètinai smulkios, bet gilios. Tiriamoji prieš pirmają procedūrą savo pilvo, sẻdmenų ir kojų būklę įvertino labai blogai. Atlikus procedūrų kursą matoma, kad strijos išbalo, ne tokios gilios, oda skaistesnè. Kairiosios pusès klubų srityje strijos ne tokios gilios, bet išlikęs nemažas jų tinklas. Dešiniosios pusès klubų srities strijos taip pat tapo ne tokios gilios, jų tinklas ne toks ryškus (1 pav.). Prieš paskutinę procedūrą tiriamoji įsivertino savo savijautą labai gerai, o problemines kūno vietas - gerai. Atliekant

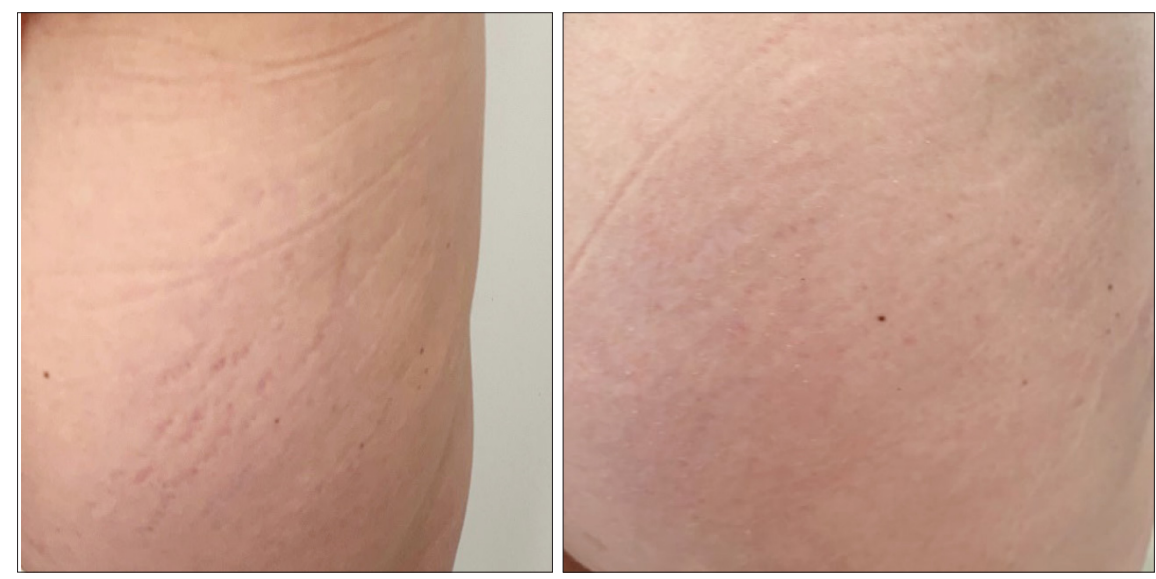

Dešiniosios pusès sėdmenų sritis prieš pro- Dešiniosios pusės sėdmenų sritis po 10 procedūrų cedūras

2 pav. 34 metų tiriamosios strijų vaizdas sẻdmenų srityje prieš ir po procedūrų

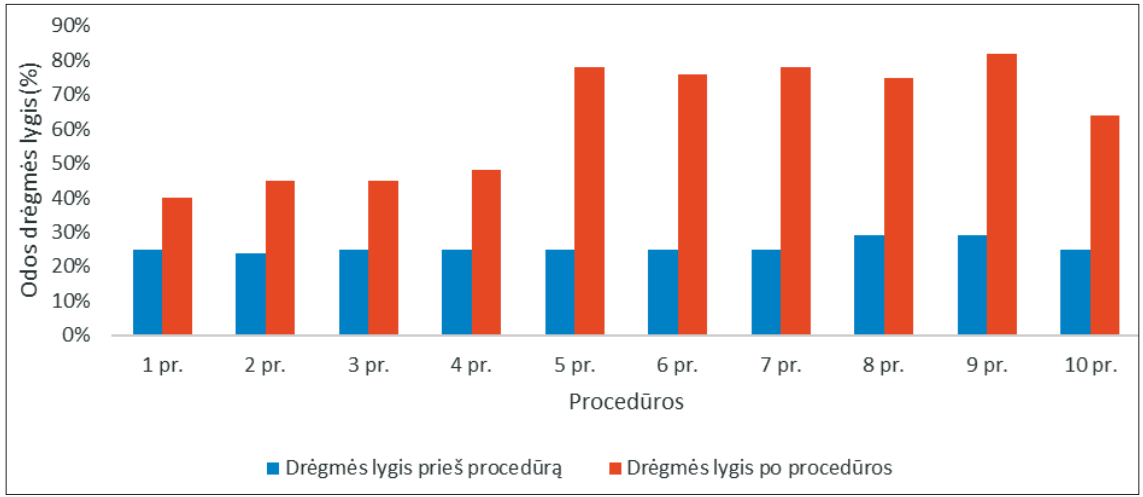

3 pav. 34 metų tiriamosios odos drègmės pokyčiai procedūrų kurso metu pr.-procedūra 
vizualinę apžiūrą po procedūrų matyti, kad baltų strijų tinklas, kuris lokalizavosi klubų srityje, yra ne toks intensyvus, kai kurių strijų kraštai išplaukę. Vertinant dešiniosios pusès sėdmens sriti, matyti, kad strijos ne tik išbalo, bet pasidare ne tokios gilios, sunkiau matomos (1 pav.).

Vertinant dešiniosios pusès sėdmens odą, matomi pokyčiai akivaizdūs - strijos tapo išbalusios, ne tokios gilios ( 2 pav.).

Vertinant drègmės pokyčius odoje, nustatyta, kad jau po pirmosios procedūros drègmès lygis nežymiai padidèjo (15 proc.). Maksimalus drègmès šuolis buvo aštuntą-devintą procedūrą, kai drègmès lygis prieš procedūrą buvo aukščiausias (29 proc.). Labiausiai drègmès lygis kilo iki 82 proc. po 9 procedūrų (53 proc.) (3 pav.).

16 metų tiriamajai pradedant procedūrų kursą, matomi odos pažeidimai sèdmenų srityje: išsidessčiusios smulkios, baltos spalvos strijos. Prieš pirmają procedūrą tiriamoji savijautą ịsivertino vidutiniškai, o klubų, sẻdmenų ir kojų odos būklę vertino labai blogai. Atlikus procedūrų kursą nustatyta, kad strijos buvo neryškios, negilios, tačiau po paskutinès procedūros oda šiek tiek paraudo (4 pav.). Dešiniosios pusès sėdmens srityje strijas sunku įžiūrèti, jos tapo ne tokios ryškios. Vertinant probleminių odos vietų pokyčius matyti, kad tamsios spalvos strijos pašviesėjo, o baltos spalvos pasidare ne tokios gilios (4 pav.).

Vertinant kairiosios pusés juosmens srities strijas, matyti, kad jos neryškios, matomas ryškus odos pasausèjimas. Nors po procedūrų juosmens srityje oda šiek tiek paraudo, tačiau strijos buvo pablukusios, ribos neryškios (5 pav.). 16 metų tiriamoji, atvykusi ị paskutinę procedūrą, savo savijautą ịvertino labai gerai, o kūno būklę - gerai.

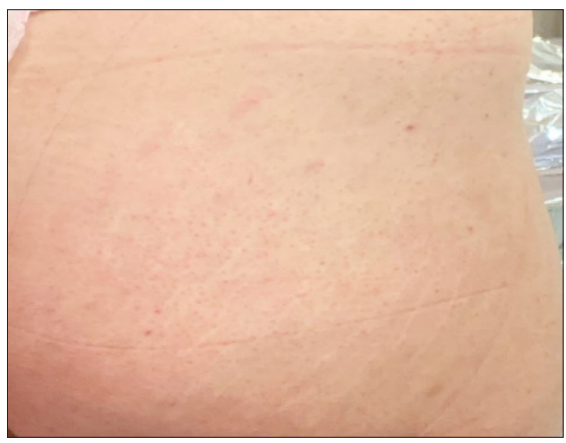

Dešiniosios pusès sẻdmenų sritis prieš procedūras
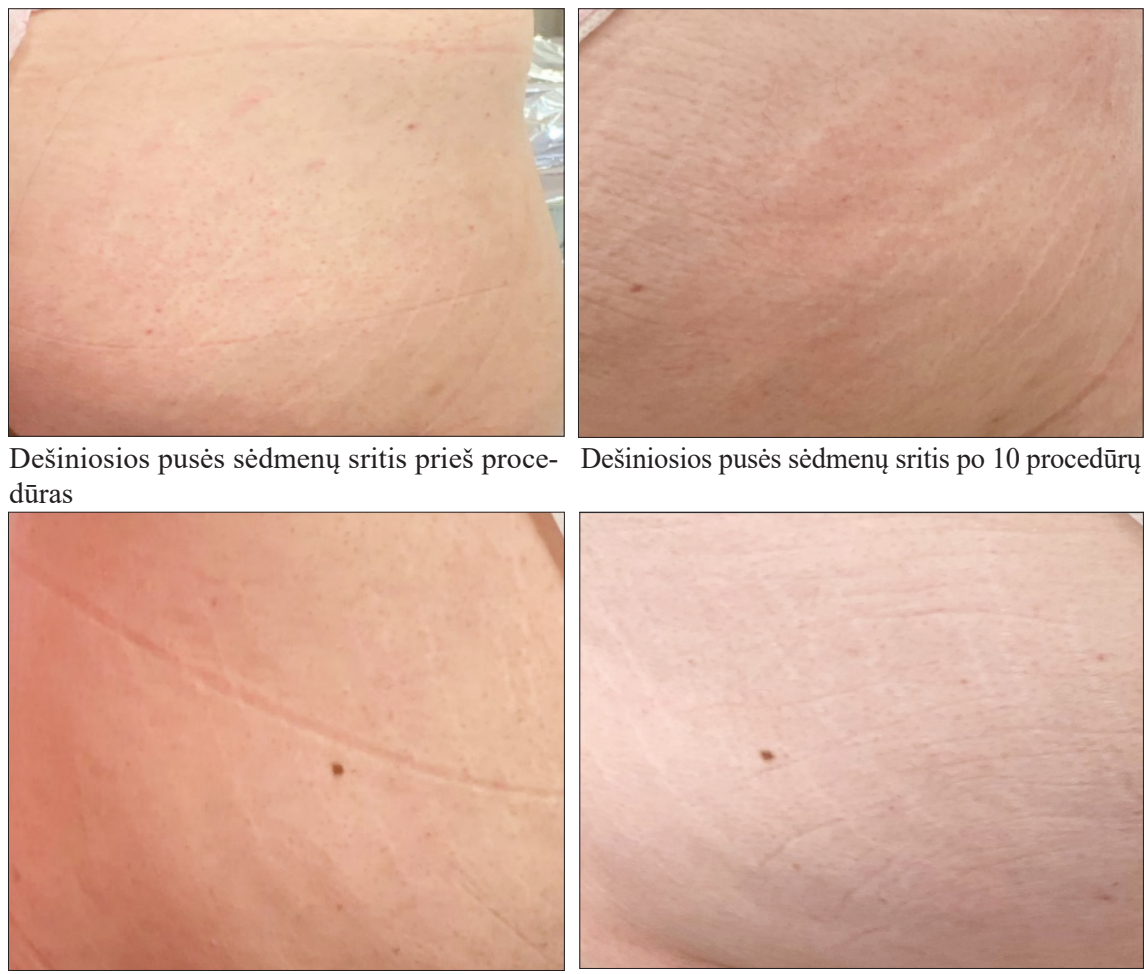

Dešiniosios pusès sėdmenų sritis po 10 procedūrų

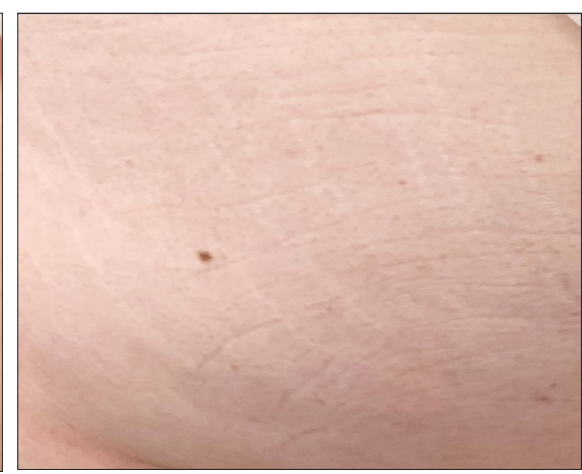

Kairiosios pusės sėdmenų sritis prieš procedūras Kairiosios pusès sẻdmenų sritis po 10 procedūrų 4 pav. 16 metų tiriamosios strijų vaizdas sẻdmenų srityje prieš ir po procedūrų
Analizuojant 16 metų tiriamosios odos drègmès lygio pokyčius (6 pav.), nustatyta, kad šios tiriamosios oda sausa. Prieš pirmają procedūrą odos drègmès lygis siekè 36 procentus. Žemiausias odos drègmès rodiklis buvo ketvirtą, penktą ir paskutinę procedūrą, kai siekè tik 25 procentus. Didžiausias drègmès šuolis nustatytas po antros (47 proc.) ir aštuntos procedūros (54 proc.), tai rodo, kad nors drègmès ir nedaug, bet ji išlieka odoje.

\section{Diskusija}

Šio tyrimo tikslas buvo nustatyti cheminio šveitimo procedūrų su glikolio rūgštimi poveikị skirtingo amžiaus moterų strijų paveiktai odai. Tyrime dalyvavo dvi moterys. Amžius - 16 ir 34 metu. Gauti rezultatai parodè, jog glikolio rūgšties procedūros strijų paveiktą odą teigiamai paveiké tiek jauno, tiek vyresnio amžiaus moterims. Mūsų atveju geresni rezultatai buvo 34 metų tiriamosios. Nežiūrint ị tai, strijų valdymas yra problemiškas ir prieštaringas, nes siūloma daugybe būdų spręsti strijų problemas. Mūsų atveju striju pažeista oda pagerèjo, tačiau rezultatas nebuvo labai akivaizdus, todèl pritariama V. Mazzarello ir kt. [12] nuomonei, kad procedūras su glikolio rūgštimi reikètų kartoti bei derinti su kitomis priemonemis ar būdais. Tyrimo rezultatai taip pat atskleidè, kad 70 proc. glikolio rūgšties naudojimas 15 proc. pagerino strijų būklę ir šis poveikis laikèsi apie 6 mènesius, todèl galima daryti prielaidą, kad procedūras reikètų periodiškai kartoti ar derinti su kitais būdais [12]. Panašūs rezultatai gauti ir šiame tyrime, kuomet glikolio rūgšties poveikis strijų paveiktai odai po taikyto 10 procedūrų kurso buvo stebimas, tačiau nežymus. Mūsų tyrime taikant glikolio rūgšties procedūras, buvo siekiama pagerinti ne tik odos strijų būklę, bet 
ir drègmès lygi. Gautieji rezultatai parodè, kad tiriamujų odos drégmès lygis pakilo daugiau nei dvigubai. Tai labai svarbus rodiklis, kadangi vanduo yra būtinas normaliam odos ir ypač jos raginio sluoksnio funkcionavimui. Vandens praradimas iš odos turi būti kruopščiai reguliuojamas, o funkcija priklauso nuo sudetingo raginio sluoksnio pobūdžio [16]. Šios funkcijos palaikymui ir atkūrimui plačiai gali būti naudojama mūsų minèta glikolio rūgštis ir kosmetikos produktai, turintys šios rūgšties sudètyje [3]. Svarbus poveikis epidermiui yra vandens sulaikymo pajegumo padidejjimas, didinantis odos drègmès lygị ir turgorą [17]. Be to, AHA rūgštys sukelia deskvamaciją, plastifikaciją ir epidermio diferenciacijos normalizavimą, trukdydami tarpląsteliniam joniniam ryšiui, mažindami korneocitų sanglaudą ir taip sukeldami keratolizę [15].

Kalbant apie poveikị strijoms, reikètų paminèti, kad dažniausiai bet kokių priemonių ir procedūrų taikymo tikslas - sumažinti strijų paraudimą, patinimą, dirginimą, padidinti kolageno ir elastinių skaidulų gamybą, pagerinti hidrataciją ir sumažinti uždegimą [6]. Šiame atliktame tyrime galime matyti pokyčius po atlikto procedūrų kurso, kai tiriamujų strijos tapo ne tokios matomos, tamsesnès pabalo, kai kurių kraštai išbluko. Tokius rezultatus galejo sąlygoti tai, kad glikolio rūgštis stimuliuoja fibroblastų kolageno gamybą ir padidina jų proliferaciją [5]. K. Ash ir bendraautorių [1] atliktame tyrime buvo lyginamas vietinis $20 \%$ glikolio rūgšties ir $0,05 \%$ tretinoino poveikis strijų paveiktai odai. Rezultatai parodè, kad abu preparatai pagerino strijų išvaizdą. Kiti autoriai pabrèžia, jog tyrimai su strijomis grožio srityje yra žemos kokybès, kadangi juose dalyvauja mažai tiriamųjų [14].

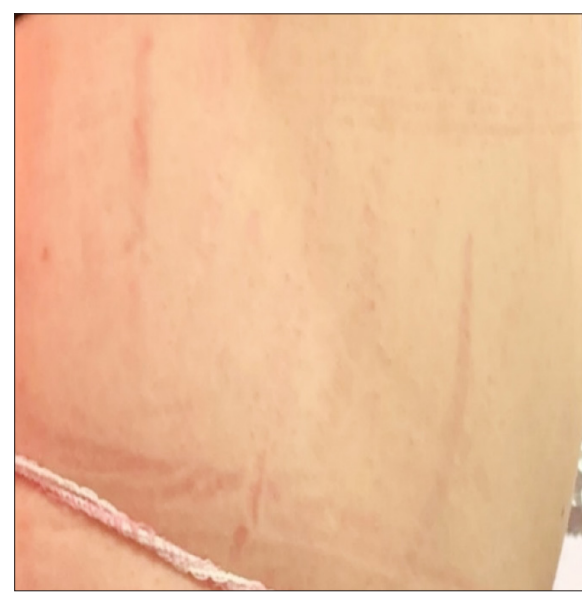

Dešiniosios pusès juosmens sritis prieš procedūras

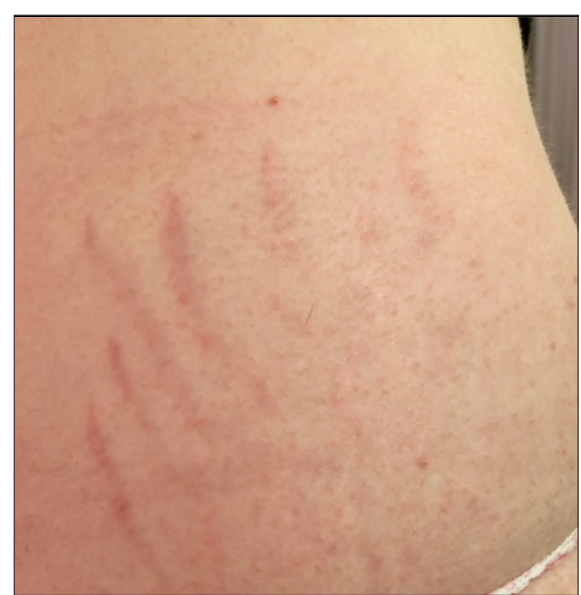

Kairiosios pusès juosmens sritis prieš procedūras Kairiosios pusès juosmens sritis po 10 procedūrų

5 pav. 16 metų tiriamosios strijų vaizdas juosmens srityje prieš ir po procedūrų

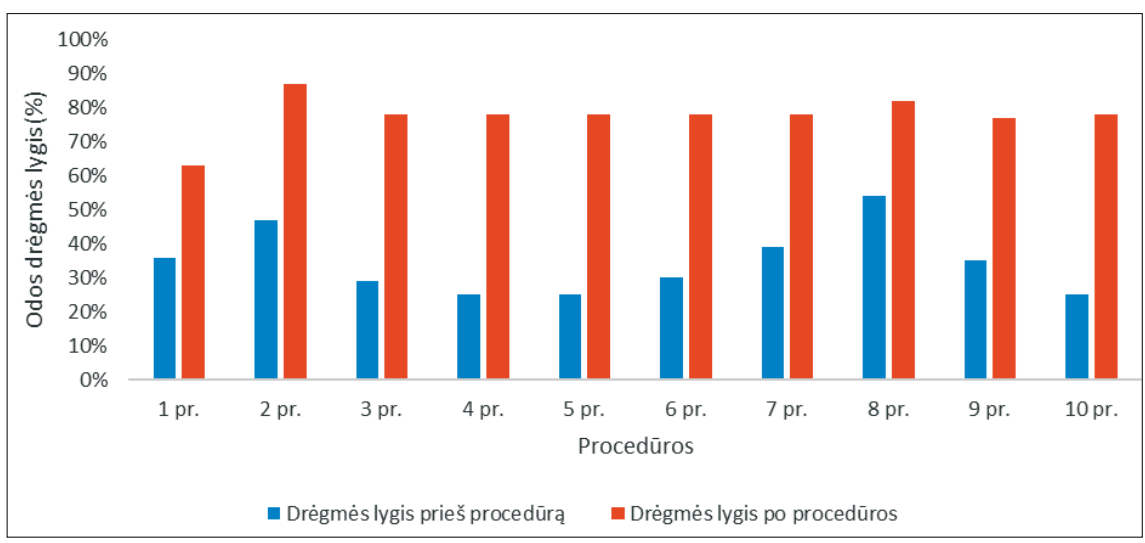

6 pav. 16 metų tiriamosios odos drègmès lygio pokyčiai prieš procedūras ir po jų pr.-procedūra 


\section{Išvados}

1. İvertinus strijų paveiktos odos būklę po dešimties glikolio rūgšties procedūrų, nustatyta, kad odos būklè pagerèjo ir teigiamai veikè skirtingo amžiaus moterų odą, tiriamųų strijos tapo ne tokios matomos, tamsesnès pabalo, kai kurių kraštai išbluko, tačiau norint dar geresnių rezultatų, rekomenduojama procedūras su glikolio rūgštimi kartoti periodiškai ir derinti su kitomis priemonèmis ar būdais.

2. Vertinant strijų paveiktos odos drègmès parametrų pokyčius, nustatyta, kad po dešimties procedūrų kurso su glikolio rūgštimi odos drègmès lygis pakito nežymiai.

\section{Literatūra}

1. Ash K, Lord J, Zukowski M, McDaniel DH. Comparison of topical therapy for striae alba (20\% glycolic acid $/ 0.05 \%$ tretinoin versus $20 \%$ glycolic acid/ $10 \%$ L-ascorbic acid). Dermatol Surg 1998;24(8):849-56. https://doi.org/10.1111/j.1524-4725.1998.tb04262.x

2. Bello DY, Farina PA, Souza MA, Cecchin D. Glycolic acid: Characterization of a new final irrigant and effects on flexural strength and structural integrity of dentin. Mater Sci Eng C Mater Biol Appl 2020;106:110283. https://doi.org/10.1016/j.msec.2019.110283

3. Babilas P, Knie U, Abels C. Cosmetic and dermatologic use of alpha hydroxy acids. JDDG 2012;10(7):488-491. https://doi.org/10.1111/j.1610-0387.2012.07939.x

4. Bogdan C, Iurian S, Tomuta I, Moldovan M. Improvement of skin condition in striae distensae: Development, characterization and clinical efficacy of a cosmetic product containing Punica granatum seed oil and Croton lechleri resin extract. Drug Des Devel Ther 2017;11:521-531. https://doi.org/10.2147/DDDT.S128470

5. Elsaie ML, Baumann LS, Elsaaiee LT. Striae distensae (stretch marks) and different modalities of therapy: an update. Dermatologic Surgery 2009;35(4):563-573. https://doi.org/10.1111/j.1524-4725.2009.01094.x

6. Forbat E, Al-Niaimi F. Treatment of striae distensae: An evidence-based approach. J Cosmet Laser Ther 2019;21(1):49-57. https://doi.org/10.1080/14764172.2017.1418515

7. Hermans JF, Pierard GE. High resolution epiluminescnece colorimetry of striae distensae. J Eur Acad Dermatol Venereol 2006;20(3):282-7. https://doi.org/10.1111/j.1468-3083.2006.01426.x

8. Issa MC, de Britto Pereira Kassuga LE, Chevrand NS, do Nascimento Barbosa L, Luiz RR, Pantaleão L, Vilar EG, Rochael MC. Transepidermal retinoic acid delivery using ablative fractional radiofrequency associated with acoustic pressure ultrasound for stretch marks treatment. Lasers Surg Med 2013:45(2):81-88. https://doi.org/10.1002/1sm.22105

9. Youssef SES, El-Khateeb EA, Aly DG, Moussa MH. Striae distensae: Immunohistochemical assessment of hormone receptors in multigravida and nulligravida. J Cosmet Dermatol 2017;16(2):279-286.

https://doi.org/10.1111/jocd.12337

10. Kornhauser A, Coelho SG, Hearing VJ. Applications of hydroxy acids: classification, mechanisms, and photoactivity. Clin Cosmet Investig Dermatol 2010;3:135-142. https://doi.org/10.2147/CCID.S9042

11. Lokhande AJ, Mysore V. Striae distensae treatment review and update. Indian Dermatol Online J 2019;10(4):380-395.

https://doi.org/10.4103/idoj.IDOJ_336_18

12. Mazzarello V, Farace F, Ena P, Fenu G, Mulas P, Piu L, Rubino C. A superficial texture analysis of $70 \%$ glycolic acid topical therapy and striae distensae. Plast Reconstr Surg 2012;129(3):589e-590e. https://doi.org/10.1097/PRS.0b013e3182419c40

13. Okano Y, Abe Y, Masaki H, Santhanam U, Ichihashi M, Funasaka Y. Biological effects of glycolic acid on dermal matrix metabolism mediated by dermal fibroblasts and epidermal keratinocytes. Experimental Dermatology 2003;12(s2):57-63. https:// onlinelibrary.wiley.com/doi/abs/10.1034/j.1600-0625.12. s2.9.x.

https://doi.org/10.1034/j.1600-0625.12.s2.9.x

14. Oakley AM, Patel BC. Stretch marks (striae). StatPearls 2020.

15. Proksch E, Lachapelle JM. The management of dry skin with topical emollients - recent perspectives. J Dtsch Dermatol Ges 2005;3(10):768-74.

https://doi.org/10.1111/j.1610-0387.2005.05068.x

16. Rabinerson D, Melze H, Gabbay-Ben-Ziv R. Striae gravidarum etiology, prevalence and treatment. Harefuah 2018;157(12):787790. https://pubmed.ncbi.nlm.nih.gov/30582313/

17. Takahashi M, Machida Y, Tsuda Y. The influence of hydroxy acids on the theological properties of stratum corneum. J Soc Cosmet Chem 1985;36:177-87.

18. Verdier-Sévrain S, Bonté F. Skin hydration: a review on its molecular mechanisms. Journal of Cosmetic Dermatology, 2007;6(2):75-82. https://doi.org/10.1111/j.1473-2165.2007.00300.x

19. Wollina U, Goldman A. Management of stretch marks (with a focus on striae rubrae). J Cutan Aesthet Surg 2017;10(3):124-129. https://doi.org/10.4103/JCAS.JCAS_118_17

20. Liu L, Ma H \& Li Y. Interventions for the treatment of stretch marks: a systematic review. Cutis, 2014; 94(2), 66-72.

\section{THE EFFECT OF COSMETIC PRODUCTS CONTAINING ACID ON SKIN AFFECTED BY STRETCH MARKS \\ M. Drozdova-Statkevičienė, R. Rauluševičienė, G. Majauskienè}

Keywords: stretch marks, atrophic scars, skin lesions, glycolic acid, alpha hydroxy acids. 
Summary

Rare boasts an even skin relief throughout the body, and stretch marks are one of the most common skin defects found in the body. These atrophic scars are less elastic, supple than normal healthy skin. While stretch marks may appear to be innocent skin defects that do not affect health, research shows that as many as 70 percent. women, 40 percent. adolescents and men and even 90 percent. pregnant women suffer from aesthetic skin damage caused by stretch marks [20]. Problems caused by stretch marks cause emotional stress, considerable cosmetic and aesthetic worries, women start to be ashamed of their body, lose sexuality. One of the innovative methods offered on the market and most commonly analyzed in the scientific literature is the effect of alpha hydroxy acids on stretch-affected skin. Therefore, the aim of this study is to determine the effects of chemical scrubbing procedures with glycolic acid on stretch marks in women of different ages. Methods: Two women aged 16 and 34 years were selected by criterion selection. Participants in the study had to meet the following criteria: stretch marks in the lower body (thighs, buttocks): blue, white, and could also complain of cellulite. In order to evaluate the effect of the applied measures on the skin affected by stretch marks, the KLAPP skin diagnostic device was used to determine the level of skin moisture before and after the procedures. Photographs were taken before and after each procedure during the study.
Subjects underwent 10 identical procedures with $70 \%$ glycolic acid. Glycolic acid exposure time was 10 minutes. After the glycolic acid neutralization process, the heating cream was wrapped in film and the CARE 7 cold function $(-10) 0 \mathrm{C}$ was used for 10 minutes for more efficient results. The procedure ends with a moisturizing lotion. Results: Comparing the results of the subjects by age, it was found that both subjects had positive results. The changes in the skin at 16 years of age were thought to be influenced by young age due to faster metabolism and skin regeneration. However, stretch marks changed more in the 34-year-old study of the buttocks, suggesting that age had no effect on the resolution of stretch marks.

Conclusions: (1) The study suggests that glycolic acid improves the condition of stretch marks, but glycolic acid procedures should be repeated and combined with other means or techniques. (2) The course of ten procedures with glycolic acid slightly changed the skin moisture parameters.

Correspondence to: r.raimonda@yahoo.com

Gauta 2021-12-06 